\title{
$\mathrm{CFD}$ 해석을 통한 하이브리드 공조시스템의 인체 온열감의 불균일성에 관한 연구
}

\author{
남 유 진, 성 민 기 ${ }^{*+}$, 송 두 삼 ${ }^{* *}$ \\ 청주대학교 건축공학과, ${ }^{*}$ 동경대학교 생산기술연구소, ${ }^{* *}$ 성균관대학교 건축공학과
}

\section{Study on Non-uniform Thermal Comfort in Hybrid Air-Conditioning System with CFD Analysis}

\author{
Yujin Nam, Minki Sung ${ }^{* \dagger}$, Doosam Song ${ }^{* *}$ \\ Department of Architecture, Cheongju University, Cheongju 360-764, Korea \\ "Institute of Industrial Science, The University of Tokyo, Tokyo 153-8505, Japan \\ *** Department of Architectural Eng., Sungkyunkwan University, Suwon 440-746, Korea
}

(Received November 6, 2010; revision received January 25, 2011)

\begin{abstract}
Recently, hybrid air-conditioning system has been proposed and applied to achieve building energy saving. One example is a system combining radiation panel with natural windinduced cross-ventilation. However, few research works have been conducted on the non-uniformity of thermal comfort in such hybrid air-conditioning system. In this paper, both thermal environment and non-uniform thermal comfort of human thermal model under various air-conditioning system, including hybrid system, were evaluated in a typical office room using coupled simulation of computation fluid dynamics, radiation model and a human thermal model.

The non-uniformity of thermal comfort was evaluated from the deviation of surface temperature of human thermal model. Flow fields and temperature distribution in each case were represented.
\end{abstract}

Key words: $\mathrm{CFD}$ (전산유체역학), Hybrid Air-conditioning System(하이브리드 공조시스템), Thermal Comfort(열쾌적성)

\section{1. 서 론}

최근 건축분야에서 건물 에너지 절감이 화두가 되 고 있는 가운데, 고효율의 에너지 성능을 가진 다양 한 공조시스템이 개발되고 있다. (1) 그러나 이러한 시스템은 에너지 절약 성능과 더불어 공조시스템 본연의 역할인 실내 거주자의 열적 쾌적성을 만족 시키지 않으면 안 된다. 이 두 가지 측면을 동시에

\footnotetext{
$\uparrow$ Corresponding author
}

Tel.: +81-3-5452-6434; fax: +81-3-5452-6432

E-mail address: mkii@iis.u-tokyo.ac.jp
만족시키기 위해 다양한 시스템을 조합한 하이브 리드 공조시스템이 제안되고 있다. Hao et al. ${ }^{(2)}$ 은 천장에 부착된 복사 패널과 자연통풍, 그리고 데시 칸트 공조를 동시에 결합한 시스템을 대상으로 실내 공기질과 에너지 효율 개선효과를 평가하였다. 또 한, Song ${ }^{(3)}$ 과 $\mathrm{Kato}^{(4)}$ 는 거실 공간에 있어서 온도 성층의 존재에 착안하여, 자연통풍과 복사냉방 패널 을 조합한 하이브리드 공조시스템을 제안하고, 대 류 - 복사 연성된 $\mathrm{CFD}$ (Computational Fluid Dynamics) 시뮬레이션 및 실증실험을 통해, 제안된 시 스템의 실내 온열환경 제어 특성, 에너지절감 효과 등을 검토하였다. 그러나 이러한 연구들은 실내 온 
열환경 평가에 있어서, 평형 상태에 있는 인체와 주 변 환경과의 열수지로부터 대표점 한 점 또는 인체 모델 전체에 대한 평균적인 PMV(Predicted Mean Vote)를 기준으로 하고 있다. 하지만, 일반적으로 인 체는 부위마다 피부표면의 온도와 현열 수지량이 달 라, 인체 부위별 온열감의 분포가 발생한다. Sakoi et $\mathrm{al}^{\left({ }^{(5)}\right.}$ 은 대부분의 공조시스템이 불균일한 온도분 포가 형성되며 이로 인해 재실자의 열적 불쾌감을 유발할 수 있다는 점에 착안하여, 피험자 실험 및 Thermal Mannequin 실험을 통해 불균일한 온열 환경하에서의 인체 온열감 평가법을 도출하였다.

본 연구에서는 자연환기와 복사냉방을 병용하는 하이브리드 공조를 포함한 몇 가지 공조시스템을 대 상으로 복사 열전달 모델을 접목한 $\mathrm{CFD}$ 시뮬레이 션을 통해 각각의 공조시스템에 의해 형성되는 온 도분포 특성, 그에 따른 인체 온열감의 불균일성에 대해서 검토하고자 한다.

\section{2. 해석방법 및 대상공간의 개요}

본 연구에서는 표준 $\mathrm{k}^{-\varepsilon}$ 모델을 사용한 3 차원 $\mathrm{CFD}$ 해석과 Monte Carlo법 및 Gebhart의 흡수계수법을 사용한 복사열전달 해석을 통해 대상 공조시스템의 열적 쾌적성을 검토하였다.

Fig. 1은 해석 대상공간으로 전형적인 오피스 실내 공간 모델이다. 크기는 $10.8 \mathrm{~m} \times 1.8 \mathrm{~m} \times 2.6 \mathrm{~m}$ 이며, 폭 은 대칭 경간의 $3.6 \mathrm{~m}$ 모듈의 반으로 설정하였다. 파 티션형 복사패널 $(8.0 \mathrm{~m} \times 1.2 \mathrm{~m})$ 과 책상 $(8.0 \mathrm{~m} \times 0.7 \mathrm{~m})$ 을 실내에 배치하고, 책상 위에는 발열체로서 컴퓨 터 $(0.5 \mathrm{~m} \times 0.5 \mathrm{~m})$ 를 배치하였다. 외부 공기는 좌측 벽 면 상부의 개구부로부터 실내로 유입되어, 우측 벽 면 상부의 개구부로 배기된다. 또한, 바닥면에는 5 개의 급기구 $(0.2 \mathrm{~m} \times 0.1 \mathrm{~m})$ 를, 천장에는 4 개의 급기 구 혹은 배기구 $(0.1 \mathrm{~m} \times 1.2 \mathrm{~m})$ 를 설정하였다. $\mathrm{PMV}$ 를 추정하기 위해서 실내에 배치한 인체 모델은 0.5

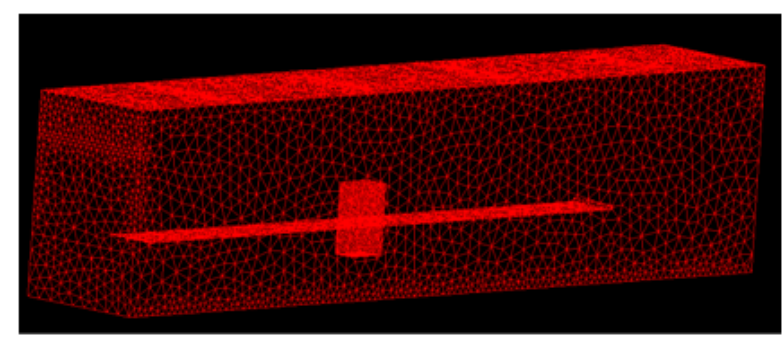

Fig. 2 CFD Model.

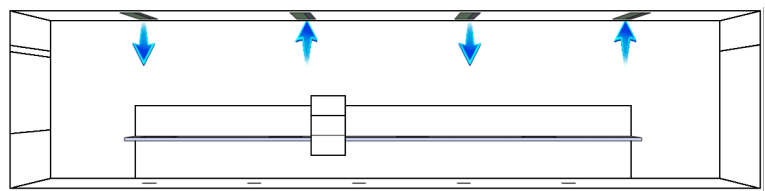

(a) Case 1 (전공기방식, 천장급기/천정배기)

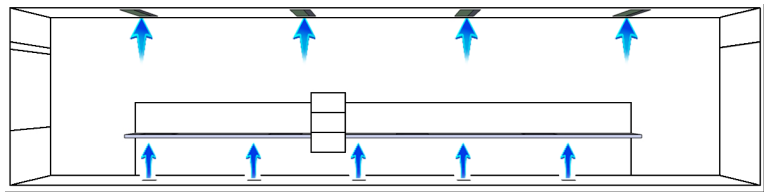

(b) Case 2(전공기방식, 바닥급기/천정배출)

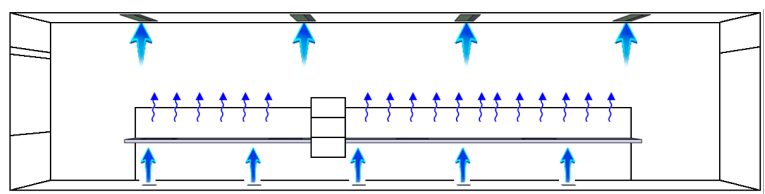

(c) Case 3(Case 2+복사냉방)

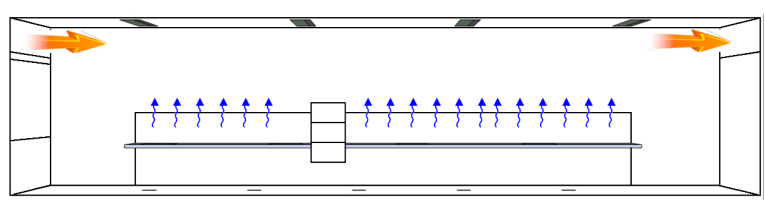

(d) Case 4(자연통풍+복사냉방)

Fig. 3 Concept of calculation cases.

$\mathrm{m} \times 0.3 \mathrm{~m} \times 0.9 \mathrm{~m}$ 의 크기의 발열체 $(120 \mathrm{~W})$ 로 설정하 였고, 인체의 국소적 온냉감을 평가하기 위해 표면 을 14 영역으로 분할하였다. Fig. 2 는 본 $\mathrm{CFD}$ 시뮬 레이션에서 사용된 해석모델을 나타낸다.

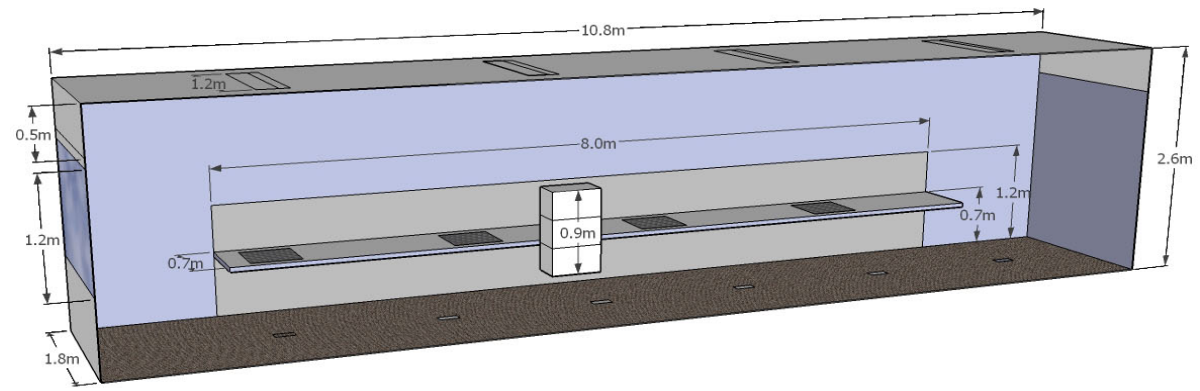

Fig. 1 Simplified office model. 


\section{3. 해석케이스 및 경계조건}

본 연구에서는 Fig. 3에서 보여주는 것과 같이 네 종류의 공조 방식을 대상으로 하여 비교 해석을 실 시하였다. Case 1 은 기존 전공기방식의 공조방식으 로 천장면에 각각 두 개의 취출구와 흡입구를 설정 하였다. Case 2는 바닥취출 공조방식으로 바닥면에 5 개의 급기구로부터 취출된 공기가 천장면의 4 개의 배기구로 배기된다. Case 3 과 Case 4 는 복사 패널 병용 형태의 하이브리드 공조시스템을 도입한 방식 으로, Case 3 은 Case 2와 같은 급배기 방식에 복사

Table 1 Calculation conditions

\begin{tabular}{c|c|c|c|c|c|c|c|c}
\hline \multirow{2}{*}{ Case } & \multirow{2}{*}{ Mode } & \multicolumn{4}{|c|}{$\begin{array}{c}\text { Inlet Temperature } \\
\left({ }^{\circ} \mathrm{C}\right)\end{array}$} & \multicolumn{3}{|c}{$\begin{array}{c}\text { Inlet Velocity } \\
(\mathrm{m} / \mathrm{s})\end{array}$} \\
\cline { 3 - 9 } & & $\mathrm{C}$ & $\mathrm{F}$ & $\mathrm{R}$ & $\mathrm{NV}$ & $\mathrm{C}$ & $\mathrm{F}$ & $\mathrm{NV}$ \\
\hline 1 & All-air & 17.4 & N.A. & N.A & N.A & 0.59 & 0 & 0 \\
\hline 2 & All-air & N.A. & 17.4 & N.A. & N.A. & 0 & 1.40 & 0 \\
\hline 3 & R+Case2 & N.A. & 22.0 & 17.0 & N.A. & 0 & 1.40 & 0 \\
\hline 4 & R+NV & N.A. & N.A. & 10.3 & 30 & 0 & 0 & 0.16 \\
\hline
\end{tabular}

Table 2 Cooling load conditions

\begin{tabular}{c|c|c|c|c}
\hline $\begin{array}{c}\text { Cooling } \\
\text { Loads }\end{array}$ & Com & Lighting & $\begin{array}{c}\text { Human } \\
\text { model }\end{array}$ & Insolation \\
\hline $\begin{array}{c}\text { Total Area } \\
\left(\mathrm{m}^{2}\right)\end{array}$ & 1.00 & 0.96 & 1.74 & 2.16 \\
\hline $\begin{array}{c}\text { Total Load } \\
(\mathrm{W})\end{array}$ & 400 & 200 & $\begin{array}{c}120 \times 5 \\
(\text { person })\end{array}$ & 287 \\
\hline
\end{tabular}

Table 3 Boundary conditions for CFD simulation

\begin{tabular}{|c|c|}
\hline $\begin{array}{c}\text { Mesh } \\
\text { System }\end{array}$ & Tetra mesh $(145,000$ cell $)$ \\
\hline $\begin{array}{c}\text { Supply } \\
\text { Inlet }\end{array}$ & $\begin{array}{l}\text { kin }=3 / 2(\operatorname{Uin} \times 0.05)^{2}, \mathcal{E} \text { in }=\mathrm{Cukin}^{3 / 2} / \operatorname{lin} \\
\text { kin : kinetic energy of inflow }\left[\mathrm{m}^{2} / \mathrm{s}^{2}\right] \\
\text { Uin : velocityofinflow }[\mathrm{m} / \mathrm{s}] \\
\mathcal{E} \text { in : kinetic energy dissipation rate }\left[\mathrm{m}^{2} / \mathrm{s}^{3}\right] \\
\mathrm{C \mu}: 0.9 \\
\text { lin : Specific length scale }[\mathrm{m}] \\
\text { Absolute humidity }: 11.3[\mathrm{~g} / \mathrm{kg}]\end{array}$ \\
\hline $\begin{array}{l}\text { Supply } \\
\text { Outlet }\end{array}$ & $\begin{array}{l}\text { Velocity : Mass balanced } \\
\text { Kin, E in, Temperature : Free slip }\end{array}$ \\
\hline Wall & $\begin{array}{l}\text { No slip, wall function(Generalized log-law) } \\
\text { Front wall : Symmetry } \\
\text { Other walls : Insulated }\end{array}$ \\
\hline
\end{tabular}

패널을 추가한 형태이다. Case 4는 복사패널과 자 연통풍을 조합한 하이브리드 공조방식이다. 이것은 외기를 통풍을 통해 실내로 유입시키고, 복사냉방 패널을 통해 실내의 현열을 제거, 실내를 쾌적하게 제어하면서 공조에너지를 절감하고자 하는 것이다. 한편, 본 해석에서 사용된 수직형 복사패널은 결로 수를 아래로 모아 배수하는 방식을 채용하고 있다.

Table 1은 해석케이스 및 시뮬레이션 설정 조건 을 나타낸다. 여기서, $\mathrm{C}$ 는 천장취출구(Ceiling), $\mathrm{F}$ 는 바닥취출구(Floor), $\mathrm{R}$ 은 복사 패널(Radiation), $\mathrm{NV}$ 는 자연 통풍(Natural Ventilation), N.A.는 적용안함 (Not applied)을 뜻한다. 급기구 온도와 풍속 및 복사 냉방 패널의 온도는 종래의 공조설계에서와 같이 실 내 평균 온도를 $26^{\circ} \mathrm{C}$ 로 일정하게 제어하기 위해서 요구되는 열부하 제거량으로부터 산출되었다. 본 계 산에서는 습기 계산의 효율성을 위해, 실내 설계 온 습도 (온도 $26^{\circ} \mathrm{C}$, 상대습도 $50 \%$ )에 대한 절대습도를 취출구의 절대습도와 같게 하여, 결로가 생기지 않 는 최저 온도를 취출구 온도로 설정하였다. 식(1)과 식(2)는 공조기 및 복사 패널의 투입열량의 계산식 (6)을 각각 나타낸다.

$$
\begin{aligned}
E_{i}= & Q_{i} \times \rho \times C \times\left(26-T_{i}\right) \\
E_{r a}= & q_{r a}+q_{r s}=5.0\left\{\left(\frac{M R T+273}{100}\right)^{4}-\left(\frac{T_{p}+273}{100}\right)^{4}\right\} \\
& +2.18\left(t_{r}-T_{p}\right)^{1.31}
\end{aligned}
$$

여기서, $E_{i}$ 는 공조기의 투입열량[W/ $\left./ \mathrm{m}^{2}\right], Q_{i}$ 는 송풍 량 $\left[\mathrm{m}^{3}\right], \rho$ 는 공기의 밀도 $\left[\mathrm{kg} / \mathrm{m}^{3}\right], C$ 는 공기의 정압비열 $\left[\mathrm{W} / \mathrm{kg}^{\circ} \mathrm{C}\right], T_{i}$ 는 송풍온도 $\left[{ }^{\circ} \mathrm{C}\right]$ 를 각각 나타내며, $E_{r a}$ 는 복사 패널의 투입열량 $\left[\mathrm{W} / \mathrm{m}^{2}\right], q_{r a}$ 는 복사에 의한 열 교환량 $\left[\mathrm{W} / \mathrm{m}^{2}\right], q_{s}$ 는 대류에 의한 열교환량 $\left[\mathrm{W} / \mathrm{m}^{2}\right]$, $M R T$ 는 평균복사온도 $\left[{ }^{\circ} \mathrm{C}\right], T_{p}$ 는 복사패널 표면온도 $\left[{ }^{\circ} \mathrm{C}\right], t_{r}$ 은 실내공기온도 $\left[{ }^{\circ} \mathrm{C}\right]$ 를 나타낸다.

한편, 자연통풍의 유입 풍속은 Song et al. ${ }^{(3)}$ 의 실 험치를 참조하여 설정하였다. 또한 모든 케이스에 대해 냉방부하는 동일하며, 부하요소로는 Table 2 와 같이 각각 4 대의 컴퓨터와 조명기구, 5 명의 재실 자로부터의 내부발열, 창문으로부터의 일사취득 등 이 있다. 현열 및 잠열을 포함한 인체 발열은 한 명 분을 실의 중앙에 위치한 인체모델에서 발열시키 고, 나머지 4명의 발열량은 바닥면에 균일하게 분포 시켰다. 또한, Table 3 은 CFD 시뮬레이션에서 사용 된 경계조건을 나타낸다. 


\section{4. 해석 결과}

\section{1 온도 및 기류 분포 특성}

Fig. 4는 전체 해석 케이스의 온도분포를 나타낸 다. 천장면에 급기구와 배기구를 갖는 Case 1에서 는 급기구 부근에서 낮은 온도분포를 보이고 있으 며, 인체 모델의 주변에는 다소 높은 온도분포를 보 이고 있다. 정상상태에서 실내 전체 평균 온도는 $25.5^{\circ} \mathrm{C}$ 였다. Case 2와 Case 3은 모두 바닥면에 급 기구를, 천장면에 배기구를 가지는 경우로 Case 2 에서는 Case 3 과 비교하여 급기구 취출온도가 낮기 때문에 실내 저층부에 낮은 온도분포를 보이고 있 다. 자연통풍과 복사 패널을 병용한 Case 4의 경우, 실내 평균온도가 $30.2^{\circ} \mathrm{C}$ 로 높은 온도분포를 나타내 고 있으며, 상하온도차 또한 다른 검토케이스에 비

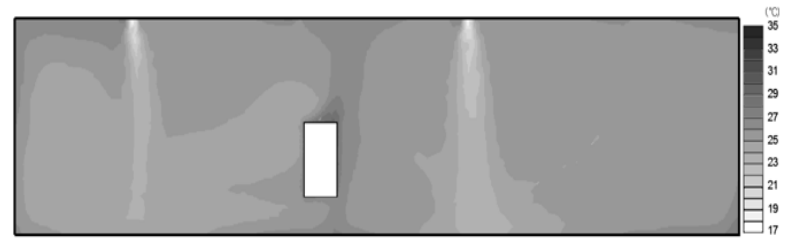

(a) Case 1 (Average temp. $25.5^{\circ} \mathrm{C}$ )

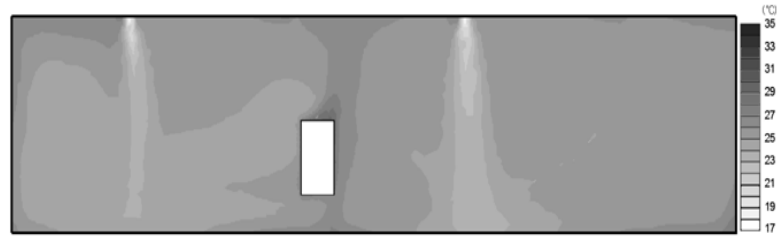

(b) Case 2(Average temp. $24.8^{\circ} \mathrm{C}$ )

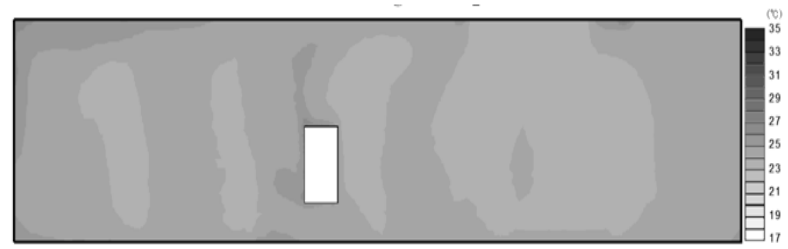

(c) Case 3(Average temp. $24.5^{\circ} \mathrm{C}$ )

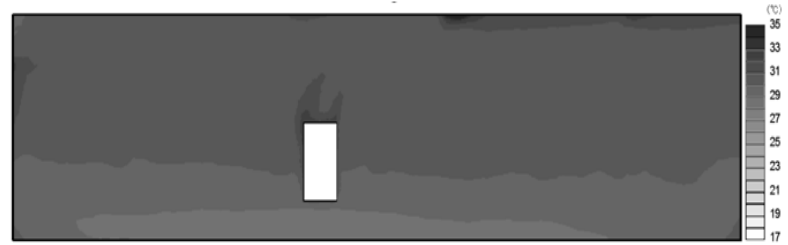

(d) Case 4(Average temp. $30.2^{\circ} \mathrm{C}$ )

Fig. 4 Temperature Fields(section through $0.78 \mathrm{~m}$ from the front).
해 현저하게 나타나고 있다. 이것은 환기의 목적으 로 $30^{\circ} \mathrm{C}$ 의 외기(상대습도 $70 \%$ )를 실내에 도입하고, 유입 풍속이 다른 경우와 비교해 작기 때문으로 판 단된다.

Fig. 5는 Fig. 4와 동일한 단면에서의 풍속분포를 나타내고 있다. Case 1에서는 급기구 부근에서의 강 한 하강류가 실내 중앙의 인체모델에 부딪치어 상 승하는 순환류가 발생하는 것을 볼 수 있다. Case 2 와 Case 3에서는 모두 바닥면 급기구로부터 강제대 류에 의한 상승기류가 관찰되는데, Case 3은 Case 2 와 비교해 급기구 온도가 높고, 그 부력의 영향으 로 보다 상승류의 세력 범위가 넓어져 있다. Case 4 에서는 고온다습한 외기가 실 상부로 유입되어, 실 내 공기와의 온도차, 밀도차로 인해 실 상부를 통과 하면서 실내에서 발생하여 실 상부에 체재하는 열 을 배출하는 결과를 보이고 있다.

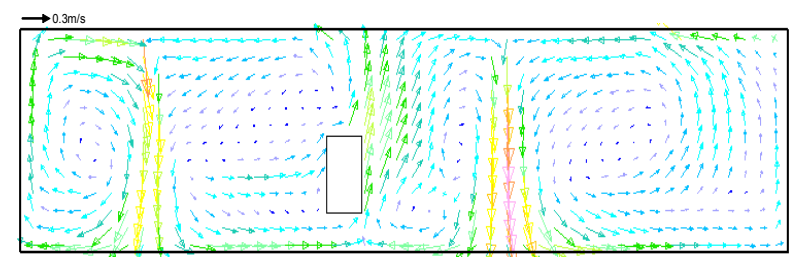

(a) Case 1

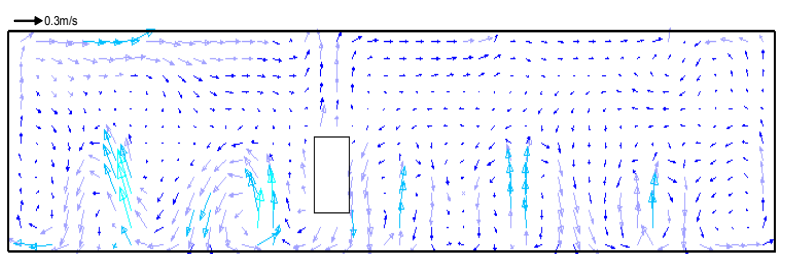

(b) Case 2

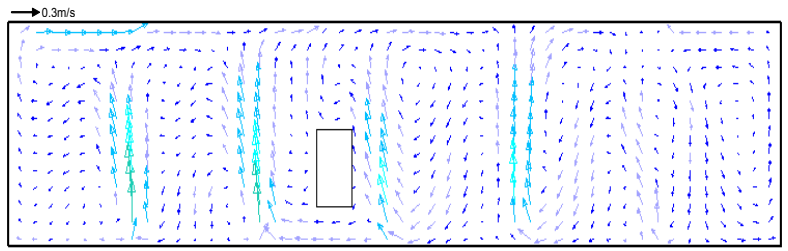

(c) Case 3

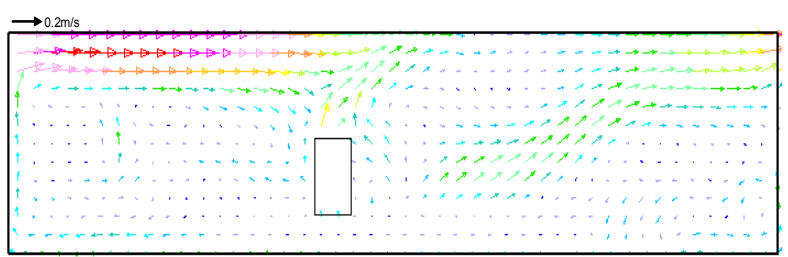

(d) Case 4

Fig. 5 Flow Fields(section through $0.78 \mathrm{~m}$ from the front). 
Fig. 6, Fig. 7은 각각 인체모델 주변의 온도, 풍 속분포를 보이고 있다. Fig. 6에 보이는 것과 같이 모든 케이스에서 인체모델 상부에 발열에 의한 상 승류가 관찰되고 있다. 특히 Case 4에서는 상승류 가 현저하게 나타나고 있다.

Fig. 7에서, Case 1의 경우, Fig. 4(a)에서도 관찰 된 것과 같이, 인체모델 주변에 급기구로부터 배기 구에 이르는 큰 순환기류가 형성되고 있어 비교적 빠른 풍속분포를 보이고 있다. 또한, 바닥취출공조 를 실시하고 있는 Case 3의 경우, 인체모델 전면에 설치된 복사냉방 패널의 영향으로 인체모델 주변에 낮은 온도를 형성하면서, 주변 기류 또한 약한 분포 를 보이고 있다. Case 4에서는 Fig. 3(d)과 같이 실 내 상하부에 뚜렷한 온도성층이 형성되고 있으며, 이러한 상하온도차에 의해 하강류가 관찰된다.

\section{2 인체모델 표면에서의 PMV 분포}

공조 방식의 차이에 따른 인체의 열쾌적성의 불 균일 특성을 검토하기 위해 본 연구에서는 인체모 델 표면을 14 개의 영역으로 분할하고, $\mathrm{CFD}$ 해석 결 과를 바탕으로 인체모델 각 영영별 $\mathrm{PMV}$ 를 계산하 였다. Fig. 8은 각 부위별 PMV 평가를 위해 분할한 인체모델의 영역이다. PMV 계산을 위한 대사율 (met치) 및 착의량(clo치)은 각각 $1.2,0.5$ 로 설정하 고, PMV는 ISO-7730에 근거하여 산출하였다.

Fig. 9에 각각의 공조시스템에 대한 인체모델 각
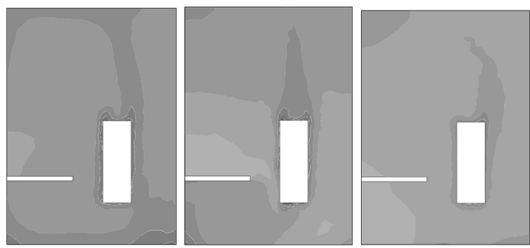

(a) Case 1 (b) Case 2 (c) Case 3

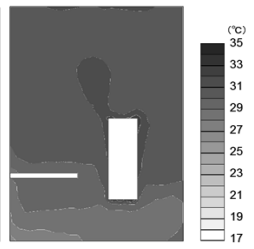

(d) Case 4
Fig. 6 Temperature Fields.

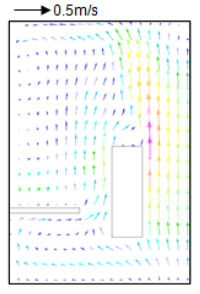

(a) Case 1

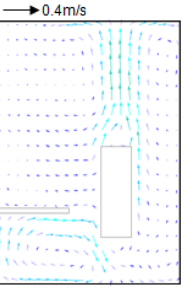

(b) Case 2

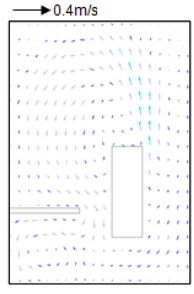

(c) Case 3

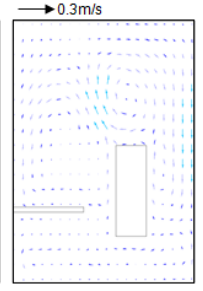

(d) Case 4
Fig. 7 Flow Fields.

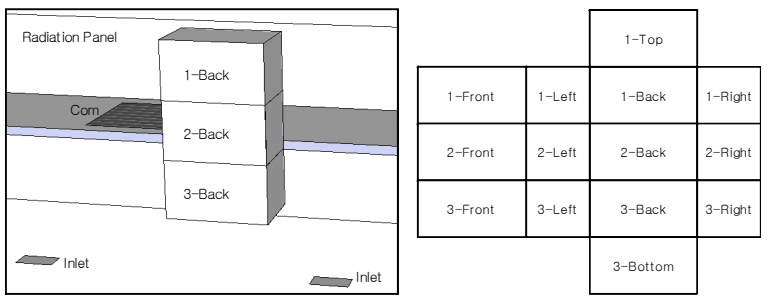

Fig. 8 Human Model.

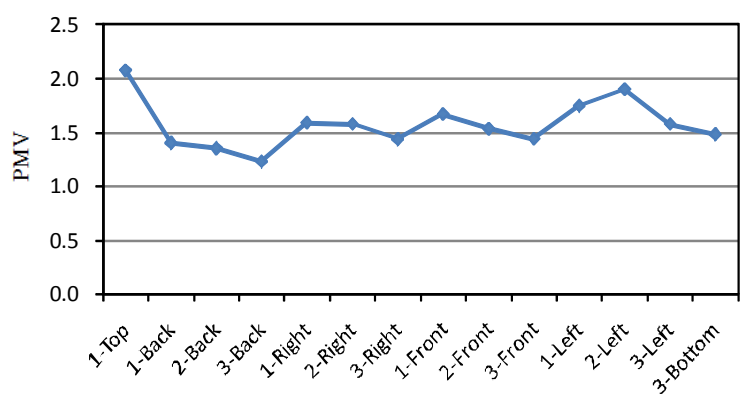

(a) Case 1

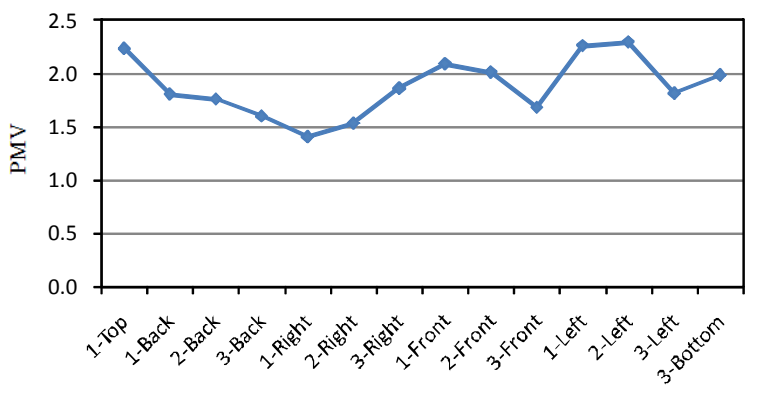

(b) Case 2

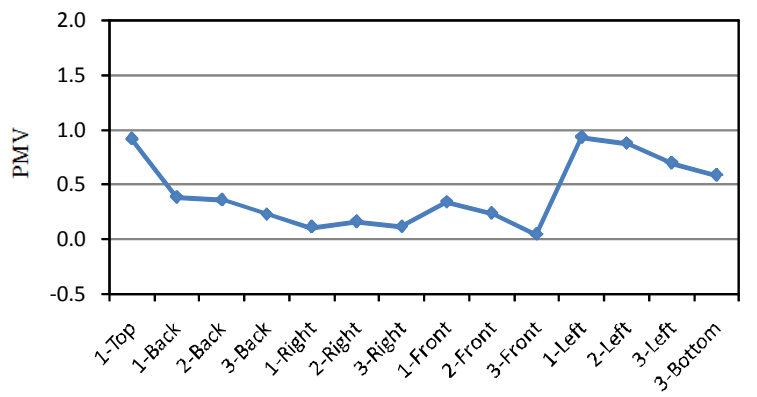

(c) Case 3

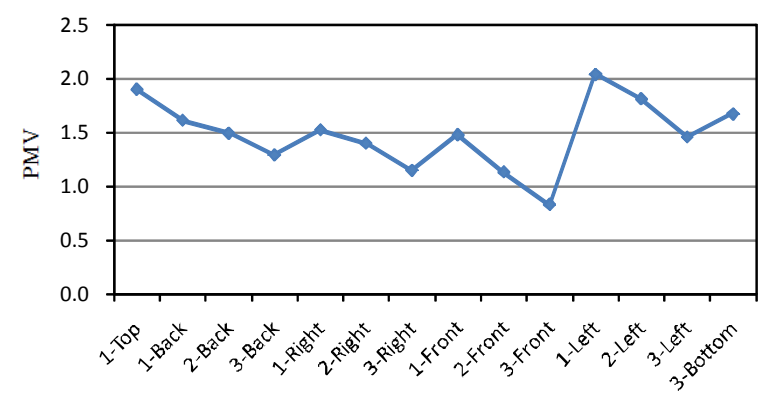

(d) Case 4

Fig. 9 Calculation Results of PMV. 
Table 4 Calculation results of PMV

\begin{tabular}{c|c|c}
\hline Case & Average PMV & Standard deviation \\
\hline 1 & 1.57 & 0.21 \\
\hline 2 & 1.88 & 0.27 \\
\hline 3 & 0.43 & 0.31 \\
\hline 4 & 1.48 & 0.31 \\
\hline
\end{tabular}

영역별 PMV 분포를 나타내고 있다. Table 4 는 인 체모델 전체의 PMV 평균치와 각 영역별 차이를 나타내는 표준편차이다. 모든 케이스에서 각 부위 별 열쾌적성에 차이가 발생함을 알 수 있다. 또한, 모든 케이스에서 인체모델의 좌측부위의 PMV치가 우측보다 높게 나타남을 알 수 있는데, 인체 좌측 전방에 위치한 컴퓨터 및 창으로부터의 복사의 영 향에 의한 것으로 판단된다.

Case 1과 Case 2에서는 전 영역에 걸쳐 PMV치 가 높게 나타나고 있으며, 전체 평균치는 각각 1.56 , 1.88 이다. 검토한 4 가지 공조방식 중에서 공기 냉방 방식을 취하고 있는 Case 1 과 Case 2의 PMV치가 높게 나타났다. 그러나 표준편차는 Case 1이 검토한 케이스 중에서는 가장 낮아, 인체모델의 각 부위별 온열감의 차이가 가장 적다고 할 수 있다. 바닥취출 공조를 실시하고 있는 Case 2는 상부취출, 상부배 기를 하고 있은 Case 1보다 다소 더우며 인체 모델 각 부위별 온열감의 차이도 Case 1 보다는 다소 크 게 나타나고 있다. 한편, 바닥취출방식과 복사냉방 방 식을 병용하고 있는 Case 3 의 경우, 인체모델의 평 균 PMV치는 0.41 로 검토한 케이스 중에서는 가장 낮은 값을 나타냈으며, 가장 쾌적한 결과를 나타냈 다. 동일한 냉방설계 기준하에서 가장 높은 냉방효 율을 나타낸다고 할 수 있다. Case 4 는 $30.0^{\circ} \mathrm{C}$ 의 높 은 온도의 외기를 도입하였음에도 불구하고, Case 1 , Case 2와 비교하면 인체모델 PMV 평균치는 낮 은 값을 보이고 있다. 이것은 비록 인체모델 주변의 공기온도가 높아도 복사냉방 패널과의 복사열교환을 통해 낮은 PMV치가 보장됨을 알 수 있다. 그러나 복사냉방 패널을 적용하고 있는 Case 3 , Case 4의 경우, 인체모델 주변의 온도성층으로 인해 인체모 델 각 부위별 $\mathrm{PMV}$ 치의 차이가 발생하고 있는 것 을 알 수 있다.

\section{5. 결 론}

본 연구에서는 복사해석을 연성한 $\mathrm{CFD}$ 해석을
통해, 각 공조방식 별 인체모델의 온열감 및 각 부 위별 온열감의 불균성에 대해 검토하였다. $\mathrm{CFD}$ 해 석 결과에 기초하여, 인체모델의 PMV치를 산출한 결과, 복사패널과 공기식 공조방식을 병용한 방식에 서의 인체모델 평균 PMV가 0.43 으로 가장 낮아 열 적 쾌적성이 가장 우수한 것으로 나타났다. 하지만, 인 체모델 부위별 $\mathrm{PMV}$ 를 평가한 결과, 복사냉방 패널 을 병용한 하이브리드 공조시스템이 기존 공기식 공 조방식에 비해 인체 전체의 평균적인 온열감은 향상 시킬 수 있으나, 복사패널 및 발열체의 위치나 표면 온도 등에 따라, 각 부위별 열적 불균일성은 다소 높 아짐을 정량적으로 확인하였다. 또한 자연환기와 복 사패널을 병용한 방식에서는 인체모델 주변의 공기 온도가 $30.2^{\circ} \mathrm{C}$ 로 비교적 높음에도 불구하고 복사패 널과의 열교환을 통해 상대적으로 낮은 $\mathrm{PMV}(1.48)$ 를 얻을 수 있음을 알 수 있었다. 향후, 인체 온열생 리모델 및 공조 제어모델을 조합한 수치해석을 실 시하여, 공조 소요에너지량과 인체 쾌적성과의 관 련성에 대해 상세히 검토할 예정이다.

\section{참고문헌}

1. IPCC Fourth Assessment Report, International Panel on Climate Change, 2007(http:// www.ipcc.ch/ipccreports/ar4-syr.htm).

2. Hao, X. and Zhang, G. et al., 2007, A combined system of chilled ceiling, displacement ventilation and desiccant dehumidification, Building and Environment, Vol. 42, pp. 3298-3308.

3. Song, D., Kato, S. et al., 2002, Study on cross ${ }^{-}$ ventilation with radiational panel cooling for hot and humid regions, ASHRAE Transactions, Vol. 21, pp. 1-6.

4. Kato, S., Murakami, S. and Chang, H. et al., 1999, Hybrid air-conditioning based on natural and mechanical ventilation in office buildings, Indoor Air 99.

5. Sakoi, T. et al., 2006, Study on Evaluation $\mathrm{Me}^{-}$ thod for Non-uniform Thermal Environment : Part 1-Human Subject Experiments under Non-uniform Radiant Fields, Transaction of Society of Heating, Air-Conditioning and Sanitary Engineers of Japan, Vol. 112, pp. 23-32 (Japanese).

6. Ma, S. and Sunaga, N., 2005, An Experimen- 
tal Study on the Thermal Performance of Ceiling Radiant Cooling by Water Flow on Roof : Study on the Roof Water Flow Radiant Cooling System Part 1, Journal of Environmental Engineering (Transactions of AIJ) Vol. 590, pp. 29-35

7. ASHRAE HANDBOOK, 1993, Fundamentals, Chapter 8, Physiological Principles and thermal comfort.

8. Murakami, S. and Kato, S. et al., 2001, Indoor climate design based on CFD Coupled simulation of convection, radiation, and HVAC con- trol for attaining a given PMV value, Building and Environment, Vol. 36, pp. 701-709.

9. Omori T., Taniguchi H. and Kudo K., 1990, Monte-Carlo simulation of indoor radiant environment, International Journal for Numerical Methods in Engineering, Vol. 30, No. 4, pp. 615-628.

10. Kim, T. and Kato, S. et al., 2001, Indoor cooling/heating load analysis based on coupled simulation of convection, radiation and HVAC control, Building and Environment, Vol. 36, pp. 900-908. 